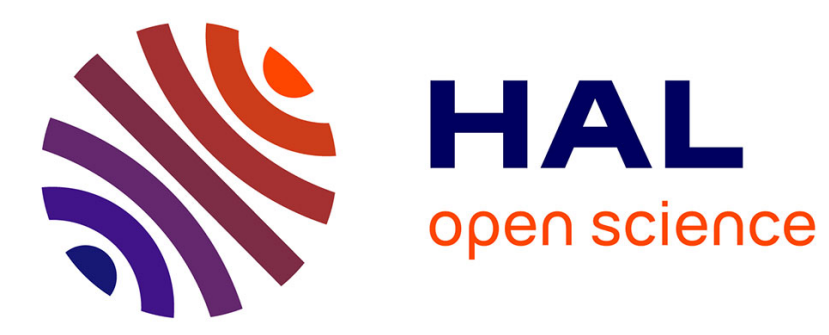

\title{
Spatially explicit competition in a mixed planting of Araucaria cunninghamii and Flindersia brayleyana
}

\author{
Jerome Vanclay, David Lamb, Peter Erskine, David Cameron
}

\section{To cite this version:}

Jerome Vanclay, David Lamb, Peter Erskine, David Cameron. Spatially explicit competition in a mixed planting of Araucaria cunninghamii and Flindersia brayleyana . Annals of Forest Science, 2013, 70 (6), pp.611-619. 10.1007/s13595-013-0304-x . hal-01201507

\section{HAL Id: hal-01201507 \\ https://hal.science/hal-01201507}

Submitted on 17 Sep 2015

HAL is a multi-disciplinary open access archive for the deposit and dissemination of scientific research documents, whether they are published or not. The documents may come from teaching and research institutions in France or abroad, or from public or private research centers.
L'archive ouverte pluridisciplinaire HAL, est destinée au dépôt et à la diffusion de documents scientifiques de niveau recherche, publiés ou non, émanant des établissements d'enseignement et de recherche français ou étrangers, des laboratoires publics ou privés. 


\title{
Spatially explicit competition in a mixed planting of Araucaria cunninghamii and Flindersia brayleyana
}

\author{
Jerome K. Vanclay • David Lamb • Peter D. Erskine • \\ David M. Cameron
}

Received: 18 December 2012 / Accepted: 22 May 2013 / Published online: 12 June 2013

(C) INRA and Springer-Verlag France 2013

\begin{abstract}
- Context A 20-year-old Nelder wheel planted with hoop pine (Araucaria cunninghamii Aiton ex D.Don) and Queensland maple (Flindersia brayleyana F.Muell.) in 18 spokes and 8 rings represents nominal point densities of $3,580,2,150,1,140,595,305,158,82$, and 42 stems/ha and offers an opportunity to examine competition and spatial interaction between these two species.

- Aims This study aimed to evaluate the intraspecific and interspecific competition between two contrasting tree species and to determine the distance over which competition can be observed.

- Methods Competition was estimated using Hegyi’s index, implemented using the Simile visual modeling environment, and calibrated using nonlinear least squares with PEST.

- Results Interactions were detected between pairs of stems closer than $D_{i j}<40\left(d_{i}+d_{j}\right)$ where $D$ is distance (in centimeters) and $d$ is stem diameter (in centimeters diameter at breast height). $F$. brayleyana trees surrounded by $A$. cunninghamii trees
\end{abstract}

\footnotetext{
Handling Editor: Erwin Dreyer

Contribution of the co-authors Jerome Vanclay: remeasurement, analysis, writing, and revision.

David Lamb: design, implementation, remeasurement, database management, and proofing.

Peter Erskine: remeasurement, database management, and proofing. David Cameron: design and implementation of trial.

J. K. Vanclay $(\bowtie) \cdot$ D. M. Cameron

Forest Research Centre, Southern Cross University, P.O. Box 157, Lismore, NSW 2480, Australia

e-mail: jerry.vanclay@scu.edu.au

D. Lamb • P. D. Erskine

Centre for Mined Land Rehabilitation, The University

of Queensland, Brisbane, QLD 4072, Australia

D. Lamb

e-mail: d.lamb@uq.edu.au

P. D. Erskine

e-mail: p.erskine@uq.edu.au
}

experience negligible competition, whereas A. cunninghamii surrounded by $F$. brayleyana trees suffer strong competition.

- Conclusion Forty times diameter offers a useful guide to the extent of competition in even-aged stands planted with these species. Competition can be observed empirically when pairs of trees are closer than 40 times the sum of their diameters, but the intensity of the competition may vary considerably with species.

Keywords Araucaria cunninghamii - Clinal spacing trial . Flindersia brayleyana $\cdot$ Hegyi index $\cdot$ Hoop pine . Interspecific competition $\cdot$ Nelder wheel $\cdot$ Queensland maple

\section{Introduction}

Competition is a fundamental process that shapes plant growth and provides the basis for density management of tree plantations. Despite the importance of understanding competition in production forests, relatively few studies have reported details of interspecific and intraspecific competition in mixed stands, and most publications deal with competition in a generic way by examining nonspatial measures (e.g., stand density as measured by stand basal area [BA]) and intraspecific competition in monocultural plantings (e.g., Mitchell 1975; Strub et al. 1975).

In recent years, ecologists have begun exploring the potential of polycultures to increase ecosystem productivity (Yanai 1992; Tilman et al. 1997; Hooper et al. 2005; Jones et al. 2005; Bristow et al. 2006a; Erskine et al. 2006). Forest owners have also shown increased interest in the use of tree polycultures because of their capacity to generate a wider range of goods and services than monocultures (Nichols et al. 2006; Lamb 2011). However, if the task of managing competition in a monoculture is difficult, then it is even more so in mixtures, where there are many more ways in which competition can be manifested (Forrester et al. 2011). 
It is useful to recognize two broad categories of beneficial mixtures. In one such category, the dominant process is that of facilitation, such as when a nitrogen-fixing species is planted together with a non-nitrogen fixer on an infertile soil. In this case, the growth of the latter species-and sometimes that of the whole stand - can be improved by the nitrogen-fixing species and the nitrogen it adds to the ecosystem (Forrester et al. 2006). In the second category, the species are complementary and occupy different ecological niches. This means they avoid or minimize competition and so increase overall productivity (Sheil et al. 2006; Pretzsch 2010). In such cases, the key issue is finding truly complementary species and managing stands to maximize complementarity and minimize interspecific competition.

This study seeks to contribute to an understanding of both intraspecific and interspecific competition by examining spatial interactions in a two-species Nelder (1962) trial in the humid subtropics. Specifically, it seeks to calibrate the responses of the two species to intraspecific and interspecific competition and the implications this has for the management of simple polyculture plantations.

\section{Literature}

Despite extensive literature on competition in plantation trees (e.g., Berger et al. 2008; Harrington et al. 2009; Binkley et al. 2010; Contreras et al. 2011; Weiskittel et al. 2011), relatively few studies have attempted to estimate interspecific competition in binary mixtures in a spatially explicit way (Mead 1979; Jones et al. 2005; Vanclay 2006b; Perot and Picard 2012). This is an important step to understanding competition in mixed-species plantings and towards a paradigm of strong and weak competitors (Vanclay 1994, p. 162). Much of the work on competition has focused on spatial indices for monospecific plantings (e.g., Strub et al. 1975; Fox et al. 2007; Burkhart and Tome 2012) and nonspatial indices for complex forests (e.g., Vanclay 1994; Peltoniemi and Makipaa 2011), and relatively few publications deal with spatial indices in even-aged polycultures (e.g., Coates et al. 2009; Kaitaniemi and Lintunen 2010).

Many variants of forest competition indices have been proposed and tested (e.g., Strub et al. 1975; Martin and Ek 1984; Daniels et al. 1986; Pukkala and Kolstrom 1987; Tome and Burkhart 1989; Biging and Dobbertin 1995; Soares and Tome 1999; Ledermann and Stage 2001; Miina and Pukkala 2002; Radtke et al. 2003; Woodall et al. 2003; Stadt et al. 2007; Oheimb et al. 2011). A recent classification and review offered by Weiskittel et al. (2011) illustrates the utility of Hegyi-type indices (Hegyi 1974; Holmes and Reed 1991; Mailly et al. 2003; Vanhellemont et al. 2010) that rely on the relative size of potential competitors and the distance between them.
Many experiment designs offer a weak basis for testing competition indices because regular rectangular plantings provide a limited range of intertree distances (Vanclay 2006a), and unthinned stands may be confounded by the high correlation between size and competition. An analysis of species interactions in a mixed planting of Acacia peregrina and Eucalyptus pellita (Vanclay 2006b; Bristow et al. 2006b) demonstrated the ability of competition indices to reveal species interactions, but the blocked experimental design and the rectangular spacing employed in that trial created difficulties in establishing the spatial extent of competition. The present study draws on the wide range of spacing in a Nelder (1962) design to examine more closely the spatial extent of competition in mixed plantings. Vanclay (2006a) reviewed a variety of experimental designs of interest in studying competition, and while Nelder designs have been extensively studied (Stape and Binkley 2010; Parrott et al. 2012), the current trial retains interest because it is one of very few long-established mixed-species planting with a binary mixture.

The present study deals with hoop pine (Araucaria cunninghamii Aiton ex D.Don) and Queensland maple (Flindersia brayleyana F.Muell.). These two species have been planted widely in Queensland (Vanclay 2006c; Manson et al. 2013), and hoop pine has become an important plantation species (Lamb et al. 2001). Elsewhere in southern Queensland, several ad hoc plantings with alternate-row plantings have shown that these two species can form a stable mixture over periods of up to 50 years (Lamb and Lawrence 1993). This apparent complementarity appears to be associated, at least in part, with the difference in canopy architecture (hoop pine has persistent branches and a deep crown, while maple has a shallow green crown). There is also some evidence that hoop pine has a deeper root system than maple (Lamb and Lawrence 1993). One of these alternate-row plantings exhibited increased height, bole length, and diameter and smaller branch sizes in maple when compared with a monocultural planting of maple nearby, while hoop pine appeared similar to surrounding hoop plantation in respect to these and other mensurational parameters. This observation was part of the motivation to examine this apparent synergism using a Nelder design by arranging species in spokes to provide monocultural and polycultural comparisons. Earlier reports based on this trial include an examination of early growth pasture production within the Nelder plot (Lamb and Borschmann 1998; Woldring 1998) and soil and foliar analyses (Lamb and Borschmann 1998). This work showed that maple suppressed grasses more than hoop, even at relatively low densities (Costantini 1989; Woldring 1998; Xu et al. 2002), and that the height-diameter-density relationship remained stable over time (Vanclay 2009).

The physiology of both species was monitored between August 1992 and December 1994 and revealed that density effects on maximum photosynthetic rates were most apparent 
in maple, with greater rates occurring in trees planted at low tree densities $(\leq 158$ stems/ha) than at high tree densities $(\geq 2,150$ stems/ha). In contrast, hoop had higher rates of photosynthesis at intermediate densities (305-1,140 stems/ha) than at either high or low planting densities (Lamb and Borschmann 1998; Snell 1998). Hoop maintained high water potentials when surrounding individuals of maple displayed low potentials, apparently due to the deeper rooting system in hoop, which, when coupled with low stomatal conductance, contributes to greater drought resistance (Lamb and Borschmann 1998; Snell 1998). The ability of maple to compete for soil moisture either between individuals of the same species or with individuals of deeper-rooted species is diminished when planted at high density during seasonal droughts (Lamb and Borschmann 1998).

\section{Material and methods}

A Nelder trial with two species was established on a uniform 1-ha site at Mt. Mee $\left(27^{\circ} \mathrm{S}, 153^{\circ}\right.$ E) in southeast Queensland, Australia in June 1990. The site is a former pasture on a deep krasnozem soil derived from basalt (Lamb and Borschmann 1998) and appears free of the variability that may confound productivity studies (Skovsgaard and Vanclay 2013). The two species, hoop pine (A. cunninghamii Aiton ex D.Don) and Queensland maple ( $F$. brayleyana F.Muell.), were arranged to allow an evaluation of monospecific growth as well as growth in mixed stands of various compositions (i.e., with alternate species on one or two sides; Fig. 1). The design involved 18 spokes (each at $20^{\circ}$ ) and 8 rings of trees at radii of $4.33,6.2,8.55,11.9$, $16.45,23,31.8$, and $44.3 \mathrm{~m}$, creating nominal point densities (assuming the area tessellated in annular sectors) of $3,580,2,150,1,140,595,305,158,82$, and 42 stems/ha, respectively. In addition, there were two internal "buffer" rings with 6 and 9 trees, at radii of 0.7 and $2.52 \mathrm{~m}$, corresponding to 7,400 and $3,140 \mathrm{stems} / \mathrm{ha}$ - these were not part of the formal design and did not involve the full complement of 18 spokes.

The plot was initially measured biannually during 1990 1996 and then in 1997, 1998, 2002, 2003, 2005, and 2010. Diameter (either root collar or diameter at breast height [DBH] of $1.3 \mathrm{~m}$ ) was recorded at all measures, but tree heights were recorded less frequently and only in the early years. Only some of these measurements were used in this analysis: intervals were selected to attain diameter increments that were large relative to the expected measurement precision. The seven measure dates chosen for use in subsequent analysis were 13 July 1992, 19 July 1993, 3 August 1995, 11 August 1998, 1 October 2002, 5 February 2005, and 9 July 2010. These dates provided intervals of 1, 2, 3, 4.1, 2.3, and 5.4 years. Analyses were based on stem diameter because of

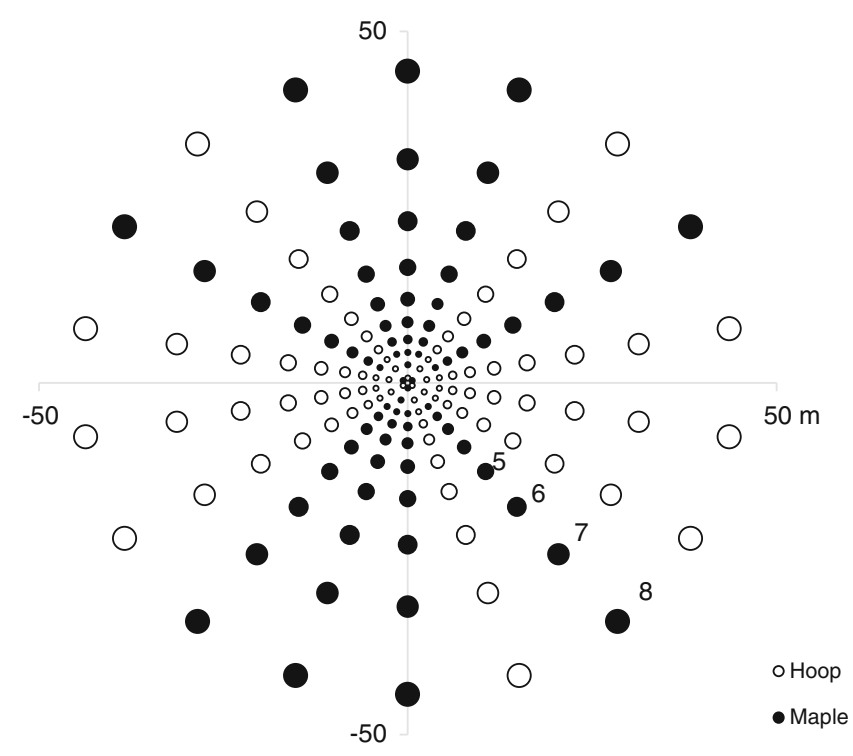

Fig. 1 Mt. Mee Nelder trial with hoop pine (A. cunninghamii) and Queensland maple (F. brayleyana). The innermost two rings (with six and nine trees) are "buffers," not part of the formal design. Symbol size is indicative of stem diameter. Ring numbers are shown for the outermost four rings

the measurement frequency, because the precision of diameter measurement is generally greater than of height measurement, and because the diameter growth response to competition is more immediate than the height response (Richardson et al. 1999). Selected measurements were used to derive estimates of periodic annual diameter increment during the period immediately following these measures (except for the 2010 measure at 20 years after planting). Competition indices were estimated from potential competitor trees within the neighborhood defined for each subject tree.

Competition was modeled using the simulation software Simile (Muetzelfeldt and Massheder 2003; Simulistics 2012), a generic modeling package that is well-suited to studying spatial interactions between individuals (Vanclay 2006b; Vanclay et al. 2006). Models were formulated and examined using Simile, and parameters were estimated by nonlinear least squares using PEST (Doherty 2005), which uses the Gauss-Marquardt-Levenberg method with Tikhonov regularization (Doherty and Skahill 2006).

Although early survival of the plantings in the trial was good, eight trees were dead or missing by the 2010 remeasure (one in 2002, one in 2003, one in 2005, and five in 2010), and the proximity of adjacent plantings compromised the design slightly, as is evident in 2009 satellite imagery (Fig. 2). The weak correlation $(r=0.021, P=0.5)$ between tree size (DBH in 2010) of trees in the outer ring and the distance to adjacent plantings provides further support for the notion that these plantings compromise the design only slightly. Figure 2 illustrates the supplementary plantings in the vicinity of the Nelder planting and to the east and the southwest of the main Nelder 


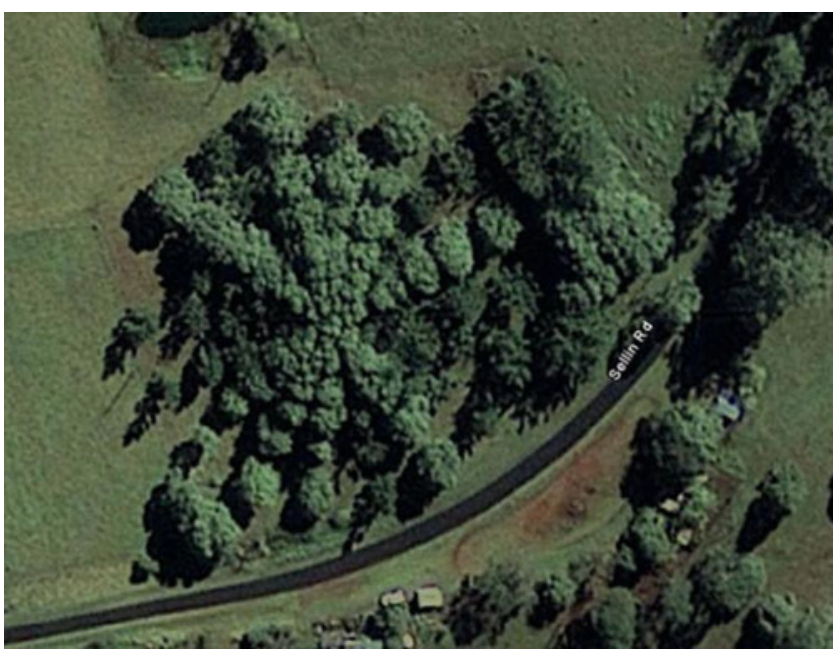

Fig. 2 Google Earth image of Mt. Mee Nelder trial, 20 July 2009 (C2012 Google, (C2012 GeoEye; $27.096^{\circ} \mathrm{S}, 152.734^{\circ} \mathrm{E}$ ), showing the two species, survival, and proximity of other plantings

design. These rectangular plantings were not always measured, so measurements taken in 2006 and 2010 were used to interpolate missing data. Interpolated diameters were used to calculate competition experienced by other trees, but were not used directly in any analysis.

An established approach to estimating competition is to rely on the assumption that observed growth can be estimated as the product of potential growth modified by a competition index (e.g., Arney 1985; Vanclay 1994; Pretzsch and Biber 2010), typically:

\section{Growth $=f($ tree size $) \times f($ competition experienced $)$}

However, growth of the wide-spaced trees has been remarkably constant during these first 20 years for both species in these trials (Fig. 3), so the size-related component of growth is subsumed within the constant term, and our analysis deals with the competition term.
Various approaches have been used to define the relevant neighborhood. Many researchers rely on constant radii (e.g., $3 \mathrm{~m}$ by Hegyi 1974; $5 \mathrm{~m}$ by Kaitaniemi and Lintunen 2010; $6 \mathrm{~m}$ by Miina and Pukkala 2002; $8 \mathrm{~m}$ by Stadt et al. 2007; $11 \mathrm{~m}$ by Contreras et al. 2011), while a few define the neighborhood in terms of tree size (e.g., proportional to crown radius, Lorimer 1983; or to tree height, Vanclay 2006b). Hegyi (1974) proposed an index $H_{j}=\Sigma_{i}\left(d_{i} / d_{j}\right) / D_{i j}$, where $d_{i}$ is the diameter of the competitor $i, d_{j}$ is the diameter of the victim $j$, and $D_{i j}$ is the distance between trees $i$ and $j$, for all trees where $D_{i j}<a\left(d_{i}+d_{j}\right)$. This index is analogous to the intuition used by field foresters who rely on relative size and separation of trees to gauge likely impact from potential competitors. An alternative index that was examined in some detail was proposed by Miina and Pukkala (2002): $M_{j}=\Pi_{i}\{1-$ $\left.\exp \left(-c D_{i j}{ }^{\mathrm{b}} / d_{i}\right)\right\}$, for all $h_{i}<a h_{j}$, where $d_{i}$ and $h_{i}$ are the diameter and height of the competitor $i$ and $D_{i j}$ is the distance between trees $i$ and $j$. Miina's index differs from most competition indices in that it indicates resource availability (cf. inverse of competition), depends only on the size and distance of potential competitors, can be computed for bare ground (Fig. 4), and offers utility for understory studies. In contrast, Hegyi's index is a classical competition index that can be computed only for competing pairs of trees. However, Miina's index is inherently constrained between zero and one and may be ill-suited to situations where interacting species exhibit complementarity (e.g., Forrester et al. 2011).

Empirical testing revealed that the Hegyi index performed better than Miina's index in the present study and that the Hegyi index performed best when the search radius was expressed as a multiple of stem diameter rather than a fixed radius. There is little to discriminate between the two indices empirically: both are highly correlated with observed increments $(r \geq 0.76)$ and with each other $(r=0.95)$. However, the Hegyi index offered a stronger correlation and avoided two drawbacks of the Miina index, namely, the
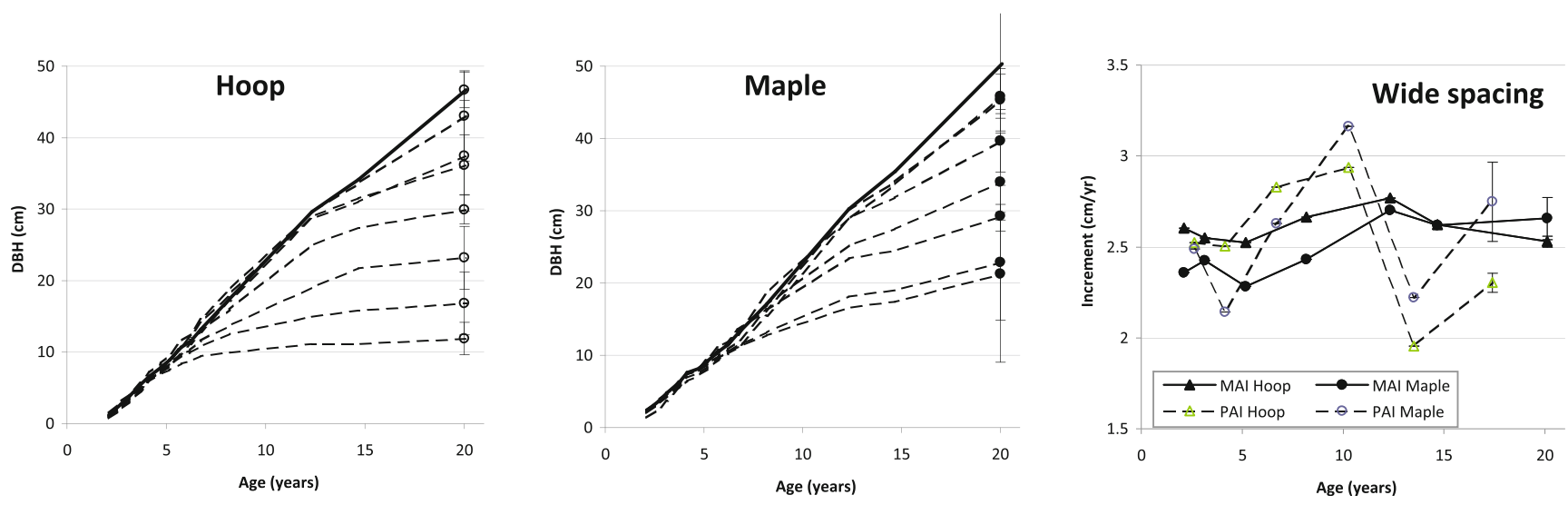

Fig. 3 Mean diameter of the two species in the Nelder trial (left and center), with lines representing the eight different "rings" in the experiment. The rightmost graph shows the growth rates of trees at the

widest spacing: the solid line is the mean annual increment (MAI, $\mathrm{DBH} / \mathrm{age})$, dashed line is periodic annual increment $(P A I, \Delta \mathrm{dbh} /$ $\Delta$ age). Vertical bars show \pm 1 standard error 


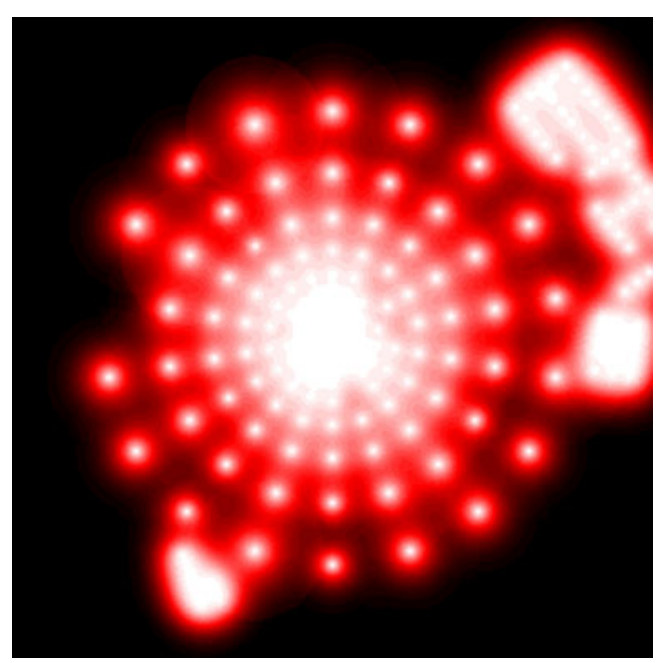

Fig. 4 Indicative competition at age 20 based on the Miina index (black indicates high resource availability; white shows low availability). Competition from trees not part of the Nelder design is evident at top right and bottom left

larger number of parameters to be estimated and the multicollinearity (Belsley et al. 2004) that existed between these parameters.

\section{Results}

The nonlinear model used to examine species interactions was:

$$
\begin{aligned}
\left(\text { DInc }_{j}\right)^{0.5}= & \beta_{0}+\beta_{1} S+\beta_{2} d_{j}+\beta_{3} S d_{j} \\
& +\beta_{4} \Sigma_{i}\left\{\left(d_{i} / d_{j}\right) / D_{i j}\right\}^{\gamma}, \\
& \text { where } D_{i j}<\lambda\left(d_{i}+d_{j}\right)
\end{aligned}
$$

where DInc ${ }_{j}$ is the periodic annual increment (in centimeters per year) of each tree $j$ suffering competition, $S$ is a dummy variable indicating species, and where $\Sigma_{i}\left\{\left(d_{i} / d_{j}\right) / D_{i j}\right\}^{\gamma}$ is a Hegyi index based on a partial sum for each species combination of all competitors $i$ seen by victim $j$. The square root transformation of $\mathrm{DInc}_{j}$ was indicated by a Box and Cox
(1964) test to stabilize variances. The terms $\beta_{1} S, \beta_{2} d_{j}$, and $\beta_{3} S d_{j}$ were included to allow for any possible differences between the two species $\left(\beta_{1} S\right)$ and any size-related growth pattern $\left(\beta_{2} d_{j}\right)$ not explained by the Hegyi index. We considered the possibility that the variables $\beta_{4}, \gamma$, and $\lambda$ could represent vectors with up to four values: a single value to describe a universal trend, two entries to reveal species differences, or four entries to expose intraspecies versus interspecies responses within species; the bold notation for $\boldsymbol{\beta}_{\mathbf{4}}$ emphasizes that this is a vector with four entries. However, poor estimates were obtained as a result of multicollinearity so the model was estimated more parsimoniously as:

$$
\begin{aligned}
\left(\mathrm{DInc}_{j}\right)^{0.5}= & \beta_{0}+\beta_{4} \Sigma_{i}\left\{\left(d_{i} / d_{j}\right) / D_{i j}\right\}^{0.5} \\
& \text { where } D_{i j}<\lambda\left(d_{i}+d_{j}\right)
\end{aligned}
$$

In Eq. 2, $\boldsymbol{\beta}_{\mathbf{4}}$ was initially estimated as a vector recognizing intraspecific and interspecific competition $\left[\beta_{\mathrm{mm}}, \beta_{\mathrm{mh}}\right.$, $\left.\beta_{\mathrm{hm}}, \beta_{\mathrm{hh}}\right]$, with $\beta_{\mathrm{mm}}$ and $\beta_{\mathrm{hh}}$ indicating intraspecific competition in maple and hoop, respectively, $\beta_{\mathrm{mh}}$ indicating competition exerted by maple on hoop, and $\beta_{\mathrm{hm}}$ indicating competition exerted by hoop on maple trees. There was no evidence to support the inclusion of the terms $\beta_{1} S, \beta_{2} d_{j}$, or $\beta_{3} S d_{j}(P>0.2)$, so these were omitted from Eq. 2 . There was strong evidence for three entries in $\beta_{4}(P<0.001)$, but the term $\beta_{\mathrm{hm}}$ was not significantly different from $\beta_{\mathrm{hh}}$, indicating that hoop pine has the same competitive effect both within and between species. There was no evidence $(P>0.1)$ to support multiple values for $\gamma$ or $\lambda$, suggesting that the distance over which competition is experienced $(\lambda)$ and the way it attenuates with distance $(\gamma)$ either does not vary greatly between these two species or cannot be estimated with the current database. Nonlinear modeling suggested that attenuation $(\gamma)$ was close to and not significantly different $(P>0.4)$ from 0.5 , the value that may be expected for spatial diffusion in two dimensions. More flexible forms of the Hegyi index-such as $\Sigma_{i}\left\{\left(d_{i} / d_{j}\right)^{\varphi} / D_{i j}{ }^{\psi}\right\}$-were examined, but these contributed no significant improvement in residuals $(P>0.1)$. The resulting parameter estimates are shown in Table 1.
Table 1 Parameter estimates for Eq. 2, calibrated for the Mt. Mee data

${ }^{\mathrm{a}}$ Calibrated relative to $\beta_{\mathrm{h}^{*}}$, the intra-specific competition observed in maple

${ }^{\mathrm{b}}$ Calibrated relative to $\beta_{\mathrm{mm}}$, the intra-specific competition observed in maple

\begin{tabular}{lllllll}
\hline Parameter & Symbol & Estimate & SE & Student's $t$ & $P$ value & Significance \\
\hline Intercept & $\beta_{0}$ & 1.599 & 0.0106 & 151.4 & $<0.0001$ & $* * *$ \\
Horizon & $\lambda$ & 40.06 & 0.0001 & 10116 & $<0.0001$ & $* * *$ \\
Attenuation & $\gamma$ & 0.510 & 0.0356 & 14.3 & $<0.0001$ & $* * *$ \\
Competition $\mathrm{m}-\mathrm{m}^{\mathrm{a}}$ & $\beta_{\mathrm{mm}}$ & -0.0308 & 0.0097 & 3.2 & 0.0008 & $* * *$ \\
Competition $\mathrm{m}-\mathrm{h}^{\mathrm{b}}$ & $\beta_{\mathrm{mh}}$ & -0.0149 & 0.0022 & 6.9 & $<0.0001$ & $* * *$ \\
Competition $\mathrm{h}^{*}$ & $\beta_{\mathrm{h} *}$ & -0.0077 & 0.0053 & 1.5 & 0.07 & - \\
\hline
\end{tabular}




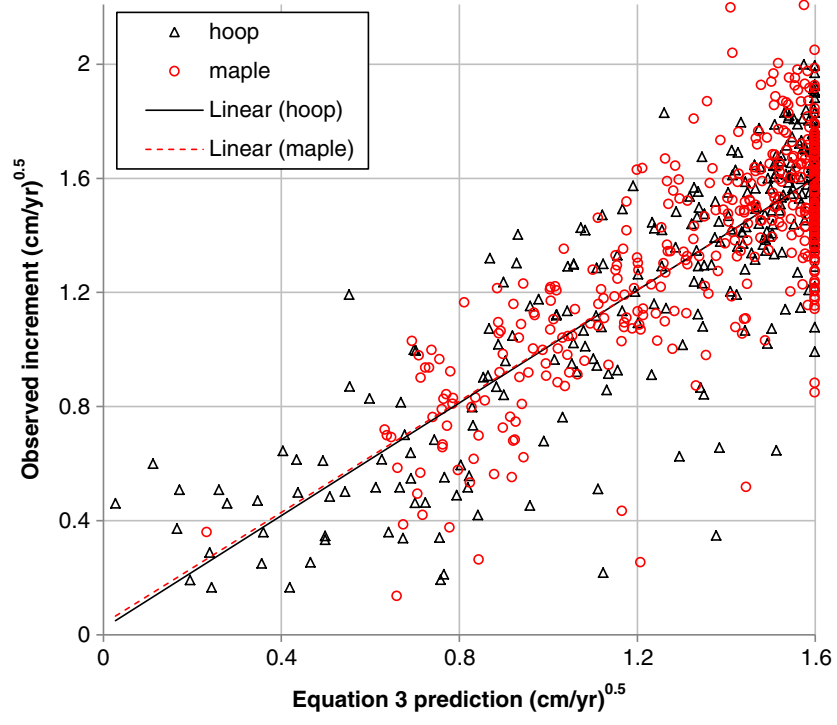

Fig. 5 Observed and predicted increments from Eq. 3

The estimates from Eq. 2 and Table 1 can be synthesized as:

$(\mathrm{DInc})^{0.5}=1.599-0.0386 H_{\mathrm{mm}}-0.0534 H_{\mathrm{mh}}-0.0077 H_{\mathrm{h} *}$

where $H_{\mathrm{mm}}, H_{\mathrm{mh}}$, and $H_{\mathrm{h}^{*}}$ are partial sums, respectively, of intraspecific competition in maple, of interspecific competition caused by maple to hoop, and of competition caused by hoop, computed as $H_{\mathrm{mm}}=\Sigma_{j} \Sigma_{i}\left\{\left(d_{i} / d_{j}\right) / D_{i j}\right\}^{0.5}$ for all $D_{i j}<40\left(d_{i}+d_{j}\right)$, where $i$ and $j$ are both maple trees, etc. While Eq. 3 is a simple empirical summary of the observed increments, it offers a surprisingly good correlation (Fig. 5), given that it spans a 20 -year period and wide range of tree sizes (Fig. 3) and stand density (42-7,400 stems/ha).

Equation 2 allowed a thorough analysis of several formulations of competition, revealed the lack of statistical support for these formulations, and established that the parsimonious formulation for competition is Eq. 3. No temporal or spatial pattern was evident in the residuals: spatial and temporal variables such as measure date, $x$ and $y$ coordinates, and spoke identifier exhibited no trend with the residuals and were all statistically nonsignificant $(P>0.1)$.

Table 1 reveals several important aspects about competition in the present study. A simple Hegyi index $\Sigma_{i}\left\{\left(d_{i} / d_{j}\right) / D_{i j}\right\}^{0.5}$ for all possible $D_{i j}<40\left(d_{i}+d_{j}\right)$ explains much of the variation (67\%) in growth rate. There is no evidence that the parameter estimates $\lambda=40$ and $\gamma=0.5$ differ between these two species. The limit of competition $\lambda=40 d$ corresponds approximately to three times the crown radius, consistent with the observations of Lorimer (1983). The limit of competition $\lambda=40 d$ lies on a broad plateau, with a wide range $26<\gamma<52$, offering a coefficient of determination better than $66 \%$ (Fig. 6). The spatial extent of this competition observed in these subtropical species is substantially greater than that commonly assumed in the computation of comparable indices for temperate species (e.g., Hegyi 1974; Kaitaniemi and Lintunen 2010; Miina and Pukkala 2002; Stadt et al. 2007).

The relationship $\beta_{\mathrm{c}}$ between the Hegyi index and observed tree growth $\left(\mathrm{DInc}^{0.5}\right)$ shows that maple exerts strong competition on both maple and hoop neighbors (1.4 times the intraspecific competition), but that hoop pine behaves quite differently, with less competitive influence (only $20 \%$ of the maple intraspecific competition).

\section{Discussion}

As expected, the Hegyi index performed better than point estimates of stand BA and the basal area of larger trees (BAL; Vanclay 1989; Biging and Dobbertin 1995). BA and BAL offered stronger correlations when the unit area adjustment was based on the distance between trees $\left(D_{i j}\right)$ rather than (more conventionally) on the search area. However, in both formulations, total stand BA performed better than BAL
Fig. 6 Relative efficiency of four measures of competition: Eq. 2 using a Hegyi index with six estimated parameters, a generic Hegyi index with four parameters and no differentiation of species, conventional stand BA (in square meters per hectare), and BAL (in square meters per hectare). BA and BAL were computed using distance to competitors (i.e., $\Sigma_{i} d_{i}^{2} / D_{i j}{ }^{2}$ ) rather than using the usual fixed search area $\left(\Sigma_{i} d_{i}^{2} / r^{2}\right.$, where $r$ is the search radius) which results in weaker correlations

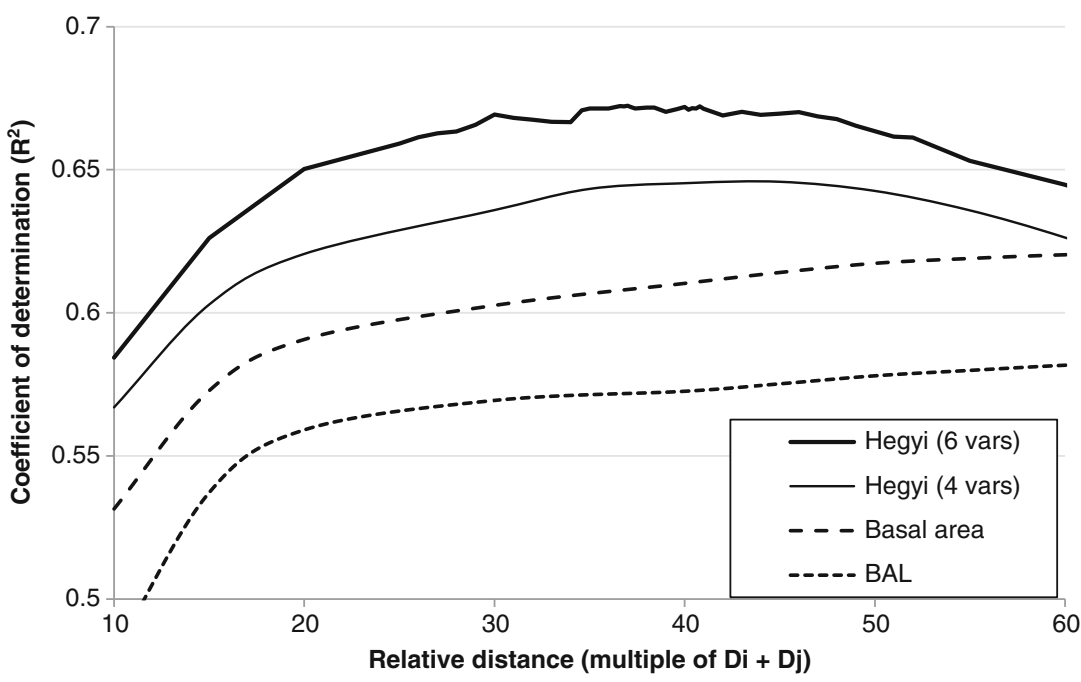


(Fig. 6), indicating that two-sided competition (i.e., for water and nutrients) dominates in this planting, rather than one-sided competition for light. The optimal radius for the Hegyi index was 40 times stem diameter with an average of 29 neighborhood trees. This distance is larger than those often reported in forestry studies, but is consistent with crown observations of Lorimer (1983) and with comparable work examining treecrop interactions (e.g., Woodall and Ward 2002, who observed reductions in wheat yields up to $30 \mathrm{~m}$ from Pinus radiata trees). During the final measurement interval, the largest trees included in the analysis were $43 \mathrm{~cm} \mathrm{DBH}$ and the most distant pair of competitors was $33 \mathrm{~m}$ apart.

Equation 3 describes the relative levels of competition observed in the trial and is not intended for prediction or extrapolation. The square root formulation of this equation confers desirable statistical properties, but limits the ability to extrapolate because extreme densities lead to problematic negative outcomes (not observed in the present data).

The strongly contrasting responses observed for interspecific competition (the effect of maple on hoop is seven times the effect of hoop on maple; Eq. 3) is somewhat surprising and warrants careful consideration. One indicator suggesting a cautious interpretation is the high correlation $(-0.8)$ between parameter estimates of interspecific competition: thus, if maple-to-hoop competition is overestimated, hoop-to-maple competition may be underestimated. However, several indicators support the implication that hoop competes only weakly with maple. The most compelling indicator is that partial residuals after fitting Hegyi indices for intraspecific competition show a substantial unexplained trend for hoop, revealing interspecific competition not yet accommodated, and a near-zero trend for maple, reflecting the minimal effect that hoop has on maple growth. These competitive differences may be explained in part by the different growth habits of the trees: as with most gymnosperms (Pallardy and Kozlowski 2008), hoop pine demonstrates strong apical dominance, and under the range of light conditions in the Nelder wheel, they maintained conical tree form. Lower branches that were heavily shaded remained on the hoop pine even in the denser plantings. Conversely, maple demonstrated a great range of growth plasticity and rapidly shed branches that became shaded. This habit and a dense canopy near the top of the tree would have allowed the maple to shade surrounding hoop pines. Both hoop and maple can tolerate a broad range of light conditions (Thompson et al. 1988), but the plasticity of maple appears to be particularly advantageous when competing with hoop pine.

It is somewhat surprising that tree size $\left(d_{j}\right)$ is not significant $(P>0.2)$ in Eq. 1 because it is well established that, in general, tree size influences growth. The conventional suggestion that collinearity between tree size and competition precludes reliable estimates of both parameters does not apply in the present case, as weak correlations exist between competition and both tree size $(0.13)$ and diameter increment $(0.67)$, in contrast to the strong correlation with the Hegyi index (Fig. 6). Nonetheless, it does seem likely that the co-development of tree size and competition hampers interpretation and that it may be insightful to impose systematic thinning on a Nelder or other clinal spacing trial to reveal further insights into the interplay between competition and tree growth.

Twenty years is a long time to await experimental results, but it is only at this point that the trial is about to exhibit density-related mortality. The 20-year life of the trial has also provided a strong database for predicting plantation performance, as the current size of the widely spaced trees approximates the sizes desired in commercial plantings. Earlier results (Lamb and Borschmann 1998) have been informative, but it appears that it is only now, near the 20th anniversary, that the plot offers definitive insights regarding densityinduced mortality (Vanclay and Sands 2009). This highlights the need to reexamine the overall approach to forest research and the desirability of prioritizing those studies requiring rigorous evaluation at the planning stage and long-term support throughout their life rather than what has become accepted as a standard 3- to 4-year term.

\section{Conclusion}

The Mt. Mee Nelder trial provided a robust database that allowed an examination of interspecific and intraspecific competition between hoop pine and Queensland maple in a polyculture. The mixture remained stable over 20 years, but the analysis showed there were differences between the two species in intraspecific and interspecific competition. Measurable competition was found to extend 40 times the diameter, with competition existing between pairs of trees for which separation $D_{i j}<40\left(d_{i}+d_{j}\right)$, where $D$ is distance (in centimeters) and $d$ is stem diameter (in centimeters). Maple was the more competitive of the two species and has high levels of intraspecific and interspecific competition. In contrast, intraspecific competition between hoop pines is modest and the competition experienced by maple from hoop competitors is negligible. This means that hoop and maple mixture at this site is not complementary and forms a winlose relationship rather than a win-win partnership. The combination of a long-established Nelder trial, coupled with individual tree modeling, has enabled new insights into the dynamics of these two species in mixed plantings.

Acknowledgments The trial was established on land generously made available by Don and Audrey Pickering, with funding provided to Greening Australia (Queensland) by the National Afforestation Program. Planting was carried out by volunteers from Greening Australia and Men of the Trees. Subsequent funding for remeasurement was provided by the Rural Industries Research and Development Corporation (RIRDC) through Project UQ-18A. Stanley Rance, Geoff Borschmann, and Jim Johnston played important roles in the design, 
establishment, and early maintenance of the trial. We also acknowledge the help received in monitoring the trial by students from the University of Queensland.

\section{References}

Arney JD (1985) A modeling strategy for the growth projection of managed stands. Can J For Res 15:511-518

Belsley DA, Kuh E, Welsch RE (2004) Regression diagnostics: identifying influential data and sources of multicollinearity. Wiley, New York, 292 pp

Berger U, Piou C, Schiffers K, Grimm V (2008) Competition among plants: concepts, individual-based modelling approaches, and a proposal for a future research strategy. Perspect Plant Ecol Evol Syst 9:121-135

Biging GS, Dobbertin M (1995) Evaluation of competition indices in individual tree growth models. For Sci 41:360-377

Binkley D, Stape JL, Bauerle WL, Ryan MG (2010) Explaining growth of individual trees: light interception and efficiency of light use by Eucalyptus at four sites in Brazil. For Ecol Manag 259:17041713

Box GEP, Cox DR (1964) An analysis of transformations. J Roy Stat Soc, B 26:211-234

Bristow M, Nichols JD, Vanclay JK (2006a) Improving productivity in mixed-species plantations. For Ecol Manag 233:193-194

Bristow M, Vanclay JK, Brooks L, Hunt M (2006b) Growth and species interactions of Eucalyptus pellita in a mixed and monoculture plantation in the humid tropics of North Queensland. For Ecol Manag 233:285-294

Burkhart HE, Tome M (2012) Modelling forest trees and stands. Springer, Dordrecht, $447 \mathrm{pp}$

Coates KD, Canham CD, LePage PT (2009) Above- versus belowground competitive effects and responses of a guild of temperate tree species. J Ecol 97:118-130

Contreras MA, Affleck D, Chung W (2011) Evaluating tree competition indices as predictors of basal area increment in western Montana forests. For Ecol Manag 262:1939-1949

Costantini A (1989) Definition of a plant zone for weed management during the establishment of Araucaria cunninghamii plantations. For Ecol Manag 29:15-27

Daniels RF, Burkhart HE, Clason TR (1986) A comparison of competition measures for predicting growth of loblolly pine trees. Can J For Res 16:1230-1237

Doherty J (2005) PEST: model-independent parameter estimation user manual, 5th edn. Watermark Numerical Computing, Brisbane, $336 \mathrm{pp}$

Doherty J, Skahill BE (2006) An advanced regularization methodology for use in watershed model calibration. J Hydrol 327:564-577

Erskine PD, Lamb D, Bristow M (2006) Tree species diversity and ecosystem function: can tropical multi-species plantations generate greater productivity? For Ecol Manage 233:205-210

Forrester DI, Bauhus J, Cowie AL, Vanclay JK (2006) Mixed-species plantations of Eucalyptus with nitrogen fixing trees: a review. For Ecol Manag 233:211-230

Forrester DI, Vanclay JK, Forrester RI (2011) The balance between facilitation and competition interactions in mixtures of Eucalyptus and Acacia changes as stands develop. Oecologia 166:265-272

Fox JC, Bi H, Ades PK (2007) Spatial dependence and individual-tree growth models: I. Characterising spatial dependence. For Ecol Manag 245:10-19

Harrington TB, Harrington CA, DeBell DS (2009) Effects of planting spacing and site quality on 25-year growth and mortality relationships of Douglas-fir (Pseudotsuga menziesii var. menziesii). For Ecol Manag 258:18-25

Hegyi F (1974) A simulation model for managing jack-pine stands. In: Fries G (ed) Growth models for tree and stand simulation. Royal College of Forestry, Stockholm, pp 74-90, Res. Note 30

Holmes MJ, Reed D (1991) Competition indices for mixed species northern hardwoods. For Sci 37:1338-1349

Hooper DU, Chapin FS, Ewel JJ, Hector A, Inchausti P, Lavorel S, Lawton JH, Lodge DM, Loreau M, Naeem S, Schmid B, Setala H, Symstad AJ, Vandermeer J, Wardle DA (2005) Effects of biodiversity on ecosystem functioning: a consensus of current knowledge. Ecol Monogr 75:3-35

Jones HE, McNamara N, Mason WL (2005) Functioning of mixedspecies stands: evidence from a long-term forest experiment. In: Scherer-Lorenzen M, Körner C, Schulze E-D (eds) Forest diversity and function: temperate and boreal systems, chapter 6 . Springer, Berlin, pp 111-130

Kaitaniemi P, Lintunen A (2010) Neighbour identity and competition influence tree growth in Scots pine, Siberian larch, and silver birch. Ann For Sci 67:1-7

Lamb D (2011) Regreening the Bare Hills: Tropical Forest Restoration in the Asia-Pacific region. Springer, Dordrecht

Lamb D, Borschmann GA (1998) Agroforestry with high-value trees. Rural Industries Research and Development Corporation, Publication 98/ 142,59 pp. Available at https://rirdc.infoservices.com.au/downloads/ 98-142.pdf

Lamb D, Lawrence P (1993) Mixed species plantations using highvalue rainforest trees in Australia. In: Leith H, Lohmann M (eds) Restoration of tropical rainforest ecosystems. Kluwer Academic Publishers, Dordrecht, pp 101-108

Lamb D, Keenan RJ, Gould K (2001) Historical background to plantation development in the tropics: a north Queensland case study. In: Harrison SR, Herbohn JL (eds) Sustainable farm forestry in the tropics: social and economic analysis and policy, chapter 2 . Elgar, Cheltenham, pp 9-20

Ledermann T, Stage AR (2001) Effects of competitor spacing in individual-tree indices of competition. Can J For Res 31:21432150

Lorimer CG (1983) Tests of age-independent competition indices for individual trees in natural hardwood stands. For Ecol Manag 6:343-360

Mailly D, Turbis S, Pothier D (2003) Predicting basal area increment in a spatially explicit individual tree model: a test of competition measures with black spruce. Can J For Res 33:435-443

Manson DG, Schmidt S, Bristow M, Erskine PD, Vanclay JK (2013) Species-site matching in mixed species plantations of native trees in tropical Australia. Agrofor Syst 87:233-250

Martin GL, Ek AR (1984) A comparison of competition measures and growth models for predicting plantation red pine diameter and height growth. For Sci 30:731-743

Mead R (1979) Competition experiments. Biometrics 35:41-54

Mitchell KJ (1975) Dynamics and simulated yield of Douglas-fir. For Sci Monogr 17:1-39

Miina J, Pukkala T (2002) Application of ecological field theory in distance-dependent growth modelling. For Ecol Manag 161:101-107

Muetzelfeldt R, Massheder J (2003) The Simile visual modelling environment. Europ J Agronomy 18:345-358

Nelder JA (1962) New kinds of systematic designs for spacing experiments. Biometrics 18:283-307

Nichols JD, Bristow M, Vanclay JK (2006) Mixed species plantations: prospects and challenges. For Ecol Manag 233:383-390

Oheimb GV et al (2011) Individual-tree radial growth in a subtropical broad-leaved forest: the role of local neighbourhood competition. For Ecol Manag 261:499-507

Parrott DL, Brinks JS, Lhotka JM (2012) Designing Nelder wheel plots for tree density experiments. New Forests 43:245-254 
Pallardy SG, Kozlowski TT (2008) Physiology of woody plants. Academic, San Diego, $454 \mathrm{pp}$

Peltoniemi M, Makipaa R (2011) Quantifying distance-independent tree competition for predicting Norway spruce mortality in unmanaged forests. For Ecol Manage 261:30-42

Perot T, Picard N (2012) Mixture enhances productivity in a twospecies forest: evidence from a modeling approach. Ecol Res 27:83-94

Pretzsch H (2010) Forest dynamics, growth and yield. Springer, Berlin

Pretzsch H, Biber P (2010) Size-symmetric versus size-asymmetric competition and growth partitioning among trees in forest stands along an ecological gradient in central Europe. Can J For Res 40:370-384

Pukkala T, Kolstrom T (1987) Competition indices and the prediction of radial growth in Scots pine. Silva Fennica 21:55-67

Radtke PJ, Westfall JA, Burkhart HE (2003) Conditioning a distancedependent competition index to indicate the onset of inter-tree competition. For Ecol Manag 175:17-30

Richardson B, Kimberley MO, Ray JW, Coker GW (1999) Indices of interspecific plant competition for Pinus radiata in the central north island of New Zealand. Can J For Res 29:898-905

Sheil D, Salim A, Chave J, Vanclay JK, Hawthorne WD (2006) Illumination-size relationships of 109 coexisting tropical forest trees. J Ecol 94:494-507

Simulistics (2012) Simile at a glance. Simulistics Limited. Available at http://www.simulistics.com/overview.htm

Skovsgaard JP, Vanclay JK (2013) Forest site productivity: spatial and temporal variability in natural site conditions. Forestry 86:305315

Snell AJ (1998) Physiological aspects of growing cabinet timber species in plantations. In: Lamb D, Borschmann GA (eds) Agroforestry with high-value trees. Rural Industries Research and Development Corporation, Publication 98/142, pp 46-47

Soares P, Tome M (1999) Distance-dependent competition measures for Eucalyptus plantations in Portugal. Ann For Sci 56:307-319

Stadt KJ, Huston C, Coates KD, Feng Z, Dale MRT, Lieffers VJ (2007) Evaluation of competition and light estimation indices for predicting diameter growth in mature boreal mixed forests. Ann For Sci 64:477-490

Stape JL, Binkley D (2010) Insights from full-rotation Nelder spacing trials with Eucalyptus in São Paulo, Brazil. Southern Forests 72:91-98

Strub MR, Vasey RB, Burkhart HE (1975) Comparison of diameter growth and crown competition factor in loblolly pine plantations. For Sci 21:427-431

Thompson WA, Stocker GE, Kriedemann PE (1988) Growth and photosynthetic response to light and nutrients of Flindersia brayleyana F. Muell., a rainforest tree with broad tolerance to sun and shade. Aust J Plant Physiol 15:299-315
Tilman D, Knops J, Wedin D, Reich P, Ritchie M, Siemann E (1997) The influence of functional diversity and composition on ecosystem processes. Science 277:1300-1302

Tome M, Burkhart HE (1989) Distance-dependent competition measures for predicting growth of individual trees. For Sci 35:816831

Vanclay JK (1989) Site productivity assessment in rainforests: an objective approach using indicator species. In: Mohd WR, Chan HT, Appanah S (eds) Proceedings of the Seminar on Growth and Yield in Tropical Mixed/Moist Forests, 20-24 June 1988, Kuala Lumpur, Forest Research Institute Malaysia, pp 225-241

Vanclay JK (1994) Modelling forest growth and yield: applications to mixed tropical forests. CAB International, Wallingford

Vanclay JK (2006a) Experiment designs to evaluate inter- and intraspecific interactions in mixed plantings of forest trees. For Ecol Manag 233:366-374

Vanclay JK (2006b) Spatially-explicit competition indices and the analysis of mixed-species plantings with the Simile modelling environment. For Ecol Manag 233:295-302

Vanclay JK (2006c) Can the lessons from the Community Rainforest Reforestation Program in eastern Australia be learned? Int For Rev 8:256-264

Vanclay JK (2009) Tree diameter, height and stocking in even-aged forests. Ann For Sci 66:702

Vanclay JK, Sands PJ (2009) Calibrating the self-thinning frontier. For Ecol Manage 259:81-85

Vanclay JK, Prabhu R, Sinclair F (2006) Realizing community futures: a practical guide to harnessing natural resources. Earthscan, London

Vanhellemont M, Verheyen K, Staelens J, Hermy M (2010) Factors affecting radial growth of the invasive Prunus serotina in pine plantations in Flanders. Eur J Forest Res 129:367-375

Weiskittel AR, Hann DW, Kershaw JW, Vanclay JK (2011) Forest growth and yield modeling. Wiley, New York

Woldring O (1998) Pasture productivity below rainforest trees: an agroforestry trial. In: Lamb D, Borschmann GA (eds) Agroforestry with high-value trees. Rural Industries Research and Development Corporation, Publication 98/142, pp 47-48

Woodall CW, Fiedler CE, Milner KS (2003) Intertree competition in uneven-aged ponderosa pine stands. Can J For Res 33:1719-1726

Woodall GS, Ward BH (2002) Soil water relations, crop production and root pruning of a belt of trees. Agric Water Manag 53:153169

$\mathrm{Xu} \mathrm{ZH}$, Bubb KA, Simpson JA (2002) Effects of nitrogen fertilisation and weed control on nutrition and growth of a four-year-old Araucaria cunninghamii plantation in subtropical Australia. J Trop For Sci 14:213-222

Yanai RD (1992) Competitive interactions between Norway spruce and Scots pine at Gisburn Forest, NW England. Forestry 65:435-451 